DAVID LUBLIN

American University

THOMAS L. BRUNELL

University of Texas, Dallas

BERNARD GROFMAN

University of California, Irvine

LISA HANDLEY

Frontier International Electoral Consulting

\title{
Has the Voting Rights Act Outlived Its Usefulness? In a Word, "No"
}

Race-conscious redistricting remains crucial to the election of an overwhelming number of African American and Latino officials. We present descriptive evidence, easily interpretable by nonspecialists, from recent elections at the state and federal levels to support our claims. The Voting Rights Act remains a valuable tool to protect the ability of minorities to elect their preferred candidates.

The intentional creation and protection of electoral districts designed to allow minority groups, primarily African Americans and Latinos, to elect their preferred candidates to public office remain the most controversial aspects of the reauthorized Voting Rights Act. Political scientists have debated heatedly the necessity of raceconscious redistricting to elect minority officials on jurisprudential, philosophical, and empirical grounds. This article focuses on the empirical question of the relationship between the racial composition of state legislative and congressional districts and the election of African American and Latino candidates.

Political scientists have often addressed the practical question of whether or not race-conscious districts continue to play a valuable role in ensuring the election of minority legislators. One group contends that districts wherein minorities constitute a majority of the population, whatever these districts' previous value in adding diversity to the legislature, are, as a matter of empirical fact, no longer crucial to minority electoral success (Cameron, Epstein, and O'Halloran 1996; 
Swain 1995; Thernstrom 1987; Thernstrom and Thernstrom 1999). ${ }^{1}$ Another set of scholars argues that majority-minority districts play a key role in the election of African American and Latino legislators (Brunell and Grofman 2008; Davidson and Grofman 1994; Grofman and Handley 1989, 1991; Handley, Grofman, and Arden 1998; Lublin 1997) but acknowledge that minority candidates can win in some majority-white districts under special circumstances (Grofman, Handley, and Lublin 2001).

Judicial decisions about when redistricting plans are dilutive of minority voting strength (or are retrogressive in nature) have been greatly influenced by social-science research presented at trial, with jurisdiction-specific analysis of whether or not minority-preferred candidates can win election in the specific districts central to most redistricting challenges. Trial court decisions have also naturally been guided by Supreme Court decisions regarding the constitutionality of taking race into account when drawing district boundaries and on the appropriate constitutional and statutory standards to use when race is implicated. These decisions have often been influenced by more-general studies on the necessity of race-conscious redistricting to promote the election of minority-preferred candidates.

Political scientists can make a valuable contribution to the current legal and scholarly debates over race-conscious redistricting by providing information that will permit the judiciary to make an empirically informed decision about the current importance of raceconscious redistricting to the continued election of minority candidates. This article presents recent, critical data that permit fact-based judgments about the effect of race-conscious redistricting at the state and congressional levels and the continuing need for the creation and legal protection of majority-minority districts or other districts in which minorities possess a realistic opportunity to elect their candidates of choice. We follow the efforts of previous scholars to present information and analyses useful to political scientists but also easy to interpret by nonspecialists (see, for examples, Grofman and Handley 1989 and Handley, Grofman, and Arden 1998).

Although there is evidence to suggest that minority candidates are beginning to win elections in some non-minority districts, the overwhelming number of minority legislators continue to represent majority-minority districts. Furthermore, a closer examination of the evidence offered by some researchers to suggest that minority candidates are much more successful in non-minority districts than used to be the case reveals that many of these minority legislators won in districts where black and Latino constituents together formed a majority. 
Even when minorities are elected from districts that are less than majority-minority in population (whether we consider minority groups separately or in combination), these districts are often sufficiently populated by minorities that the groups constitute a majority of the Democratic Party primary electorate; thus minority candidates can win the general election with only some - often relatively low-level of white support.

There are some differences between the present-day relationship between the racial composition of districts and the probability of the election of African American or Latino candidates than existed between these variables in earlier periods. But these differences are smaller than is often claimed. Perhaps most important for the purposes of our analysis, the increase in the number of minority officeholders does not result from a diminution of levels of racially polarized voting, but rather can be largely explained by (1) the increase in the number of majorityminority districts and the rise in the success rates of minority candidates competing in these districts, and (2) white voters in the South deserting the Democratic Party in large enough numbers to make it easier in some districts for minorities to win Democratic primaries (Grofman, Handley, and Lublin 2001). ${ }^{2}$ In sum, race-conscious redistricting and the protections provided by Sections 2 and 5 of the Voting Rights Act (VRA) continue to play valuable roles in ensuring that minority-preferred representatives can gain election.

\section{Statutory and Legal Context}

When the Voting Rights Act of 1965 was amended in 1982, Congress added language to Section 2 of the Act indicating that the right to vote was illegally abridged if, "based on the totality of circumstances," it can be shown that minorities have "less opportunity than other members of the electorate to participate in the political process and to elect representatives of their choice." In the context of redistricting, this specification has been taken to mean that a redistricting plan must include districts that provide minority voters with an opportunity to elect their preferred candidates.

Section 5 of the VRA also applies to redistricting. Section 5 requires "covered jurisdictions" 3 to obtain permission for all changes in their voting practices or procedures from the U.S. Attorney General (or, alternately, the D.C. district court). According to the Supreme Court in Beer v. United States (1976), the standard for preclearance under Section 5 is "nonretrogression." Only redistricting plans that would lead to a decrease in minority voters' ability to elect their preferred candidates would be denied preclearance. ${ }^{4}$ 
When the amended act was first applied to decennial redistricting following the 1990 census, minority plaintiffs (under Section 2 of the Act), and the Department of Justice (under Section 5) forced numerous jurisdictions to alter redistricting plans that were judged to impinge upon the ability of minorities to elect the candidates they preferred. This legal action led to the creation of a host of new majority-minority districts, and the election of an unprecedented number of minority candidates.

These gains were challenged by a line of court cases beginning in 1992. In Shaw v. Reno (1993) and its progeny, the Supreme Court said that race could be taken into account during the redistricting process but that courts must engage in "strict scrutiny" (that is, apply a more-stringent standard) if they determine that race was the "predominant factor" in the construction of a redistricting plan. A court must find that the use of race is "narrowly tailored" to fulfill a "compelling governmental interest" in order for a redistricting plan to survive strict scrutiny. As a result of these cases, a number of majorityminority districts were redrawn to be less-than-majority black or Hispanic in the mid-1990s. But most majority-minority districts remained protected by Section 5 and are still offered as models to jurisdictions found to be in violation of Section 2.

On July 27, 2006, President George W. Bush signed into law the 25-year renewal of the Voting Rights Act in a form very close to that passed in 1982. The renewal means that — as has long been the casecourts will continue to be charged with determining when a given district's composition is such that it provides minority voters a realistic opportunity to elect their candidates of choice. The renewed act, especially Section 5, currently faces legal challenge. A week after passage of the extended and amended act, the Northwest Austin Municipal Utility District Number One (NAMUDNO) filed suit in the federal court in the District of Columbia, contending that Section 5 had become unconstitutional. The three-judge district court issued its opinion in May 2008: "given the extensive legislative record documenting contemporary racial discrimination in voting in covered jurisdictions, Congress's decision to extend Section 5 for another twenty-five years was rational and therefore constitutional" (Northwest Austin Municipal Utility District Number One v. Mukasey 2008). The NAMUDNO filed a notice of appeal to the U.S. Supreme Court in July 2008. On June 22, 2009, the Supreme Court left Section 5 of the VRA intact with their decision in the NAMUDNO case. Instead of vacating the preclearance section challenged by the plaintiffs, the Court focused its attention on easing the bailout provision for Section 5. Chief Justice Roberts 
authored the majority opinion that had the support of eight of nine members of the Court. Section 5 remains intact for now, but there are likely to be other cases filed in the near future testing the constitutionality of this part of the law.

Whether or not Section 5 is declared unconstitutional, Section 2 will remain in force. The renewed act and the judicial challenge to it, therefore render an analysis of the empirical relationship between the racial composition of districts and the election of minority officials especially timely. The remainder of this article provides empirical evidence regarding the importance of race-conscious redistricting for the election of minority officials to state legislatures and to the U.S. House.

\section{Empirical Evidence regarding the Links between Minority Population and Minority Representation, 1992-2005}

Table 1 presents the proportion of African American legislators in both chambers of the state legislatures, as well as the U.S. House, for 1992 and 2007 in states with substantial minority populations. ${ }^{5} \mathrm{We}$ included information separately for the South, which we defined as the 11 states of the former Confederacy, and for the 8 nonsouthern states with black populations that constituted $10 \%$ or more of the total state population, as of the 2000 census. ${ }^{6}$ The number of African American elected officials has increased both in the South and in the nonsouthern states. In the South, the proportion of black state representatives rose from $15.3 \%$ to $18.4 \%$. In the nonsouthern states, the percentage of black state representatives increased from $11.5 \%$ to 13.9\%. The proportion of African Americans in state senates also rose over the same period, climbing from $14.2 \%$ to $16.8 \%$ in the South and from $10.2 \%$ to $13.8 \%$ in the nonsouthern states. In contrast, the proportion of African Americans in U.S. House delegations changed little in the southern and nonsouthern states examined here: blacks accounted for approximately $9 \%$ of U.S. House representatives in both 1992 and 2007. The number of blacks elected to the federal House changed in some states, but the overall picture stayed essentially the same. ${ }^{7}$

Table 1 also shows the proportion of Latino state and federal legislators in 1992 and 2007 for all 10 states in which Hispanics formed more than $10 \%$ of the total 2000 population. ${ }^{8}$ The percentage of Latino state house members rose in each of the 10 states, from $10.3 \%$ across all of them in 1992 to $15.2 \%$ in 2007 . Latinos also made substantial, albeit less impressive, gains in state senates, with the overall proportion of Latino legislators climbing from $9.8 \%$ to $13.0 \%$ across the 10 


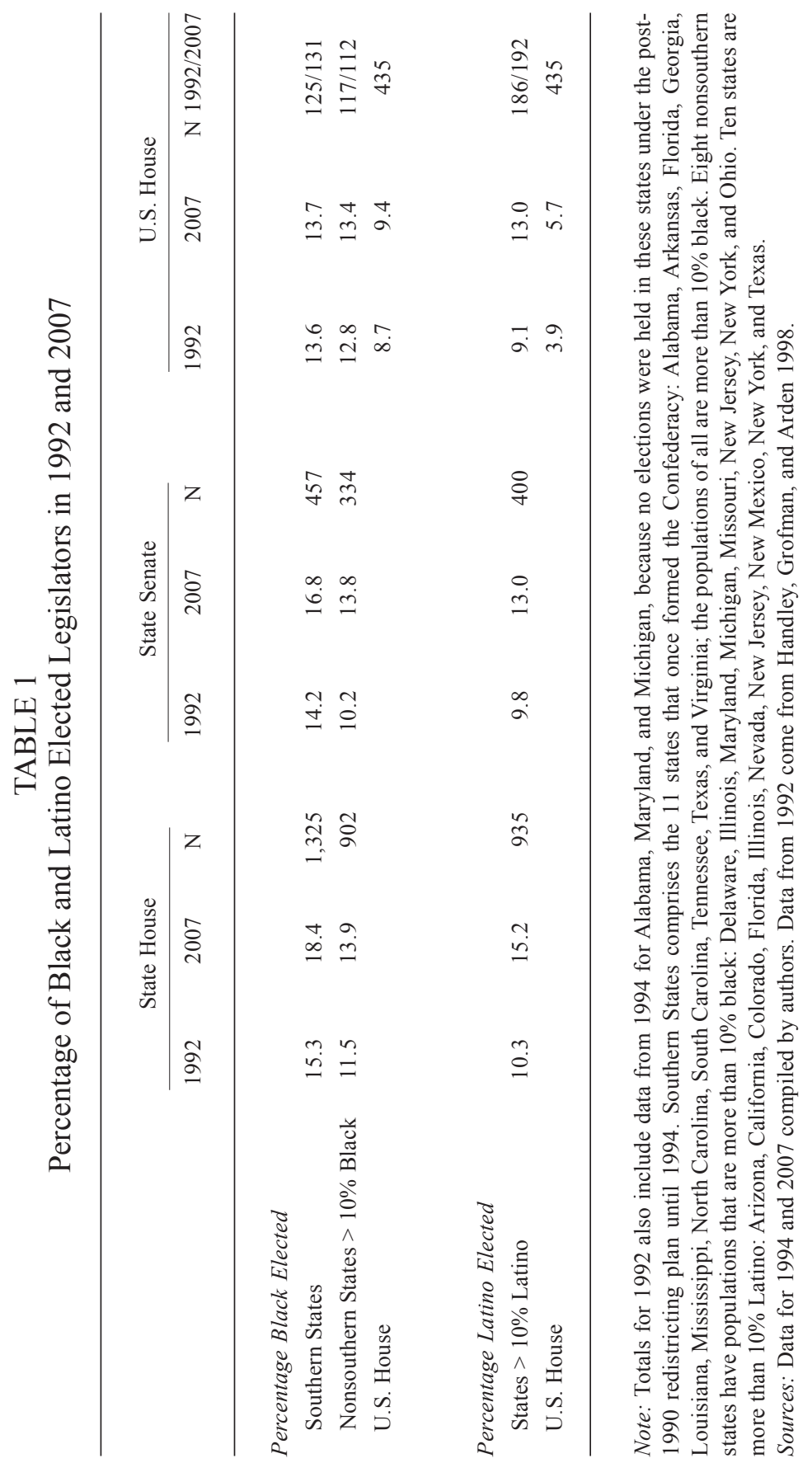


states examined here. This statistic is somewhat deceptive, however, because the percentage of Latinos in the state senate grew in only 4 of the 10 states; it remained the same in 5 states and actually declined slightly in 1. Latino officials held $13.0 \%$ of U.S. House seats in the 10 states in 2007 , compared to only $9.1 \%$ in 1992 . As in state legislatures, the gains in the number of Latinos elected were uneven across the states.

Table 1 shows that the number of African American and Latino legislators increased between 1992 and 2007. To what do we attribute this increase? Is it simply that there has been an increase in the proportion of black and Hispanic constituents in these states? If there has been an increase, then perhaps this has led to an increase in the number of majorityminority districts created, which has in turn led to an increase in the number of minorities elected to legislative office. Or maybe majorityminority districts are now more successful at electing minorities to officethat is, is there now a higher victory rate for minorities in these districts? Or perhaps minority representatives are winning in an increasing number of majority-white districts. If so, is the necessity of race-conscious redistricting declining as minority representatives win more victories in majoritywhite districts? We will explore these possibilities in the next subsection. In short, our findings indicate that although minorities now find it marginally easier to win election in majority-white districts, the vast majority of African American and Latino legislators at both the state and federal levels continue to win election from majority-minority districts. Furthermore, in most of the instances that minorities have been successful in majority-white districts, these districts have had substantial minority populations, such that minority voters control the Democratic primary.

\section{Explaining Minority Descriptive Representation}

Which sorts of districts elect African American and Latino legislators? Theoretically, minorities can win in any type of district, but primarily two sorts of districts have the ability to elect minority legislators. Minorities can win with the support of solely their own group in districts in which that group forms a majority of the electorate. Or, in another set of districts, often referred to as "coalitional" districts, minorities can win with the support of a coalition between members of their own group and another minority group or a subset of nonHispanic whites. Since discussions of racial redistricting often focus on the necessity for majority-minority districts, we will begin by examining the success of African American and Latino candidates in gaining election from districts in which their own groups, respectively, 
do and do not form a majority of the electorate. We will then address which types of coalitional districts tend to elect minority legislators, and we will provide a more-nuanced look at the relationship between the percentage of minorities in a district and that district's probability of having a minority representative. ${ }^{9}$ After all, minorities may win outside of districts in which their group forms a majority, if they can reliably attract sufficient crossover support.

African Americans and Latinos have exhibited gains in representation in both (non-Hispanic) majority-white and majority-minority (majority-black, majority-Hispanic, or majority-black-plus-Hispanic) districts. Nevertheless, the vast majority of minority legislators still win in majority-minority districts. African American legislators still win predominately in majority-black districts, and, although the number of these districts has remained relatively stable, reflecting the relatively stable black population percentages across the states we examined, black voters have been more successful at electing African American representatives in these districts. The number of majority-nonblack districts electing African American legislators has also increased slightly since 1992, but it remained quite low in 2007. Moreover, blacks and Latinos together make up a majority in many of the majority-nonblack districts won by black candidates. In other non-majority-minority districts where African American candidates are successful, minority-population concentrations are sufficiently large to virtually guarantee that minority voters will constitute a majority of the electorate in the Democratic primary, even if these voters do not form a majority of the overall electorate.

In contrast to African Americans, Latinos have experienced substantial growth in population and a parallel increase in the number of majority-Hispanic legislative districts. But like black voters electing black candidates, Hispanic voters are now more likely to elect Latino candidates in the majority-minority districts that have been created than they were in 1992 (at least with regard to state senate and congressional districts). And like African American representatives, the vast majority of Latino representatives are elected from majorityminority districts. The percentage of districts with non-Hispanic majorities represented by Latino legislators has risen since 1992, but, like the increase in the number of African American representatives elected from majority-nonblack districts, this increase has been small. Moreover, a number of the Latino representatives elected from districts with non-Latino majorities won in districts where blacks and Latinos together formed a majority - although the share of Latino victories in districts characterized by black-and-Hispanic majorities is lower than the share of African American victories in such districts. 
African Americans. Table 2 displays the percentage of majorityblack districts that elected black candidates to legislative office in 1992 and 2007. Courts usually prefer to rely on data based on the votingage or citizen voting-age population, but we used data based on the total population, to ensure the data were comparable to data available from $1992 .{ }^{10}$ African Americans were victorious in approximately fourfifths of majority-black state house districts in 1992, and that proportion rose further in 2007. ${ }^{11}$ The share of majority-black state house districts won by African Americans rose from $81.4 \%$ to $87.4 \%$ in the South, and from $80.4 \%$ to $83.9 \%$ in the nonsouthern states. As in state house elections, African Americans won the lion's share of state senate elections held in majority-black districts in 1992 and further increased their success rates in 2007, especially in nonsouthern states. Blacks represented $87.5 \%$ of the southern majority-black state senate districts in 2007-a gain of 2.8 percentage points over 1992. In the six nonsouthern states examined here, the share of majority-black state senate districts won by African Americans rose from 81.6\% in 1992 to $94.9 \%$ in 2007 , an increase of 13.3 percentage points. Black voters were more successful at electing African Americans to state legislative office in majority-black legislative districts, although the actual number of these districts remained relatively stable.

The story is slightly different at the federal level. As Table 2 shows, the number of majority-black congressional districts nationwide declined from 32 to 26, with five of the six losses occurring in the South. This decrease came in the wake of the Shaw v. Reno line of cases, in which courts deemed some majority-minority districts invalid, on the grounds that race was the predominant factor in line drawing. Such rulings gave decision makers pause in the 2000 round, when they considered drawing additional minority seats. African Americans won all but 1 of the 32 majority-black congressional districts in 1992 and all of the remaining 26 black districts in 2007.

The number of majority-black congressional districts in the South decreased between 1992 and 2007, but the number of African American congressional representatives remained stable, so African Americans obviously won some districts where black residents did not constitute a majority of the population in 2007. Table 4 confirms this supposition. Whereas blacks represented only $1.7 \%$ of districts without a black majority in 1992, these legislators represented $3.7 \%$ of such districts in 2007. Most of the gains occurred in the South. ${ }^{12}$ The share of African American victories in majority-nonblack districts also increased slightly for both state house and state senate elections in both the South and the nonsouthern states. Still, the percentage of majority-nonblack seats 
David Lublin et al.

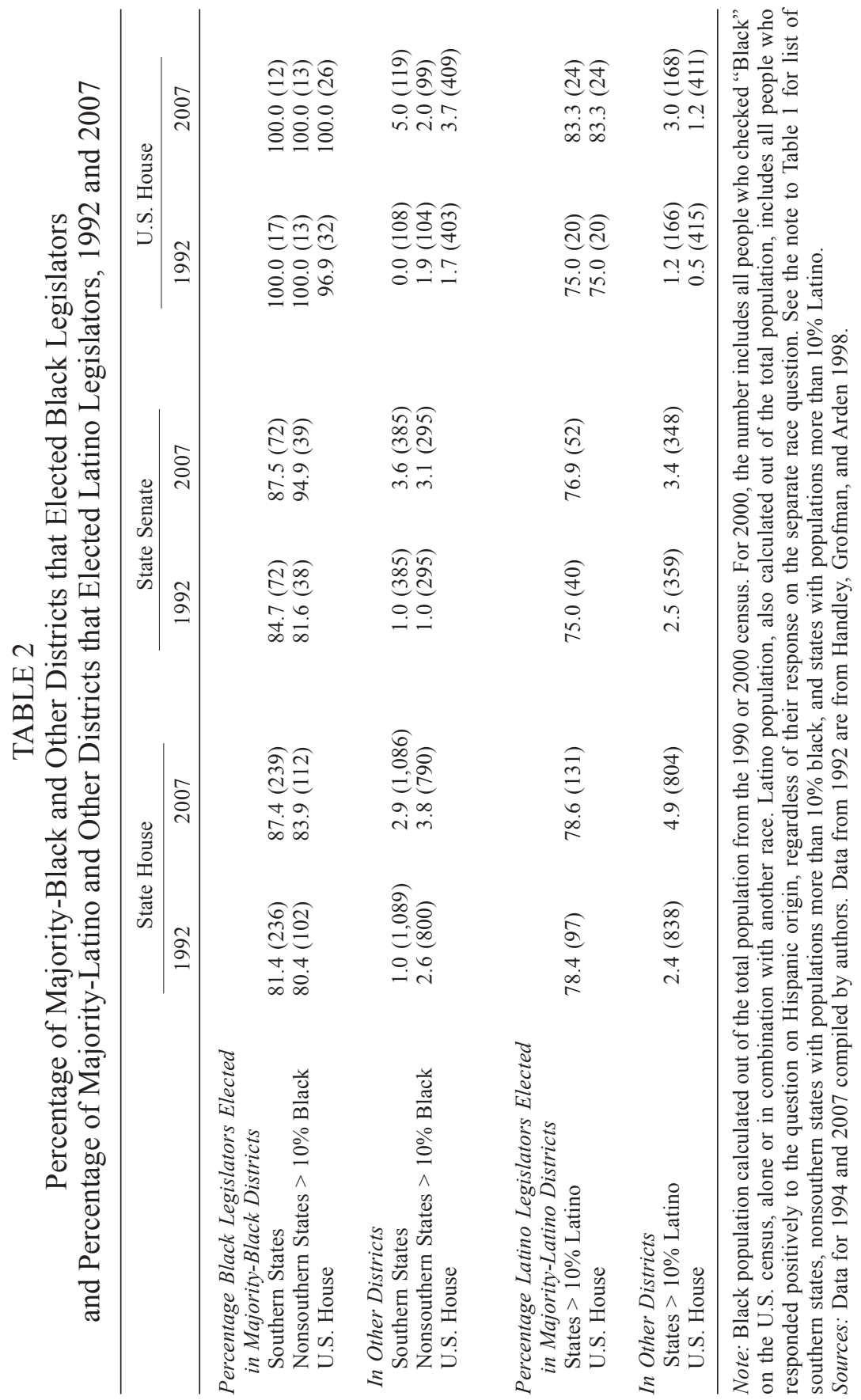


held by African American state legislators remained low. In 2007, in the South, African Americans won $2.9 \%$ of the state house districts where blacks did not form a majority and $3.6 \%$ of such state senate districts. The figures are only slightly higher for majority-nonblack districts outside the South; African Americans won 3.8\% of such house districts and $3.1 \%$ of such state senate districts in 2007 .

Do these small increases in the share of majority-nonblack districts represented by African American officeholders herald a trend toward diversification of the electoral base of black elected officials? Not if by diversification we mean districts with a sizable majority of non-Hispanic white voters. Table 3 shows the percentage of black legislators from districts with a black majority, those with a combined black-and-Latino majority, and other districts. Non-Hispanic whites form a majority in the vast bulk of "other" districts. A glance at the table makes obvious that the overwhelming majority of black legislators still win office from majority-black districts. In the South, $87 \%$ of state representatives, $82 \%$ of state senators, and $67 \%$ of U.S. House members won in districts in which blacks composed a majority of the population. In the nonsouthern states, $76 \%$ of state representatives, $82 \%$ of state senators, and $87 \%$ of U.S. House members gained election from majority-black districts.

A closer examination of the majority-nonblack districts that elected black legislators to office offers little hope of a dramatic change in the share of African American legislators elected from majoritywhite districts. Most black elected officials who won in districts without a black majority hailed from districts where blacks and Hispanics together formed a majority. In the South, a majority of the black legislators elected from outside of majority-black districts won in districts with a mixed black-and-Latino majority. Although the situation is somewhat different outside the South, especially for state senate elections, it is still true that many of the African American legislators representing majority-nonblack districts are elected from districts where blacks and Hispanics together compose a majority of the population. This finding is not surprising: because of lower citizenship and voter turnout rates, Latinos almost invariably form a substantially smaller share of the electorate than they do of the population; consequently, blacks make up a higher proportion of the electorate than their share of the population suggests. The election of blacks from these combined majority-minority districts simply cannot be attributed to a great diversification of the electoral base of black officials - districts with non-Hispanic white majorities elect only a small share of black legislators. ${ }^{13}$ 
David Lublin et al.

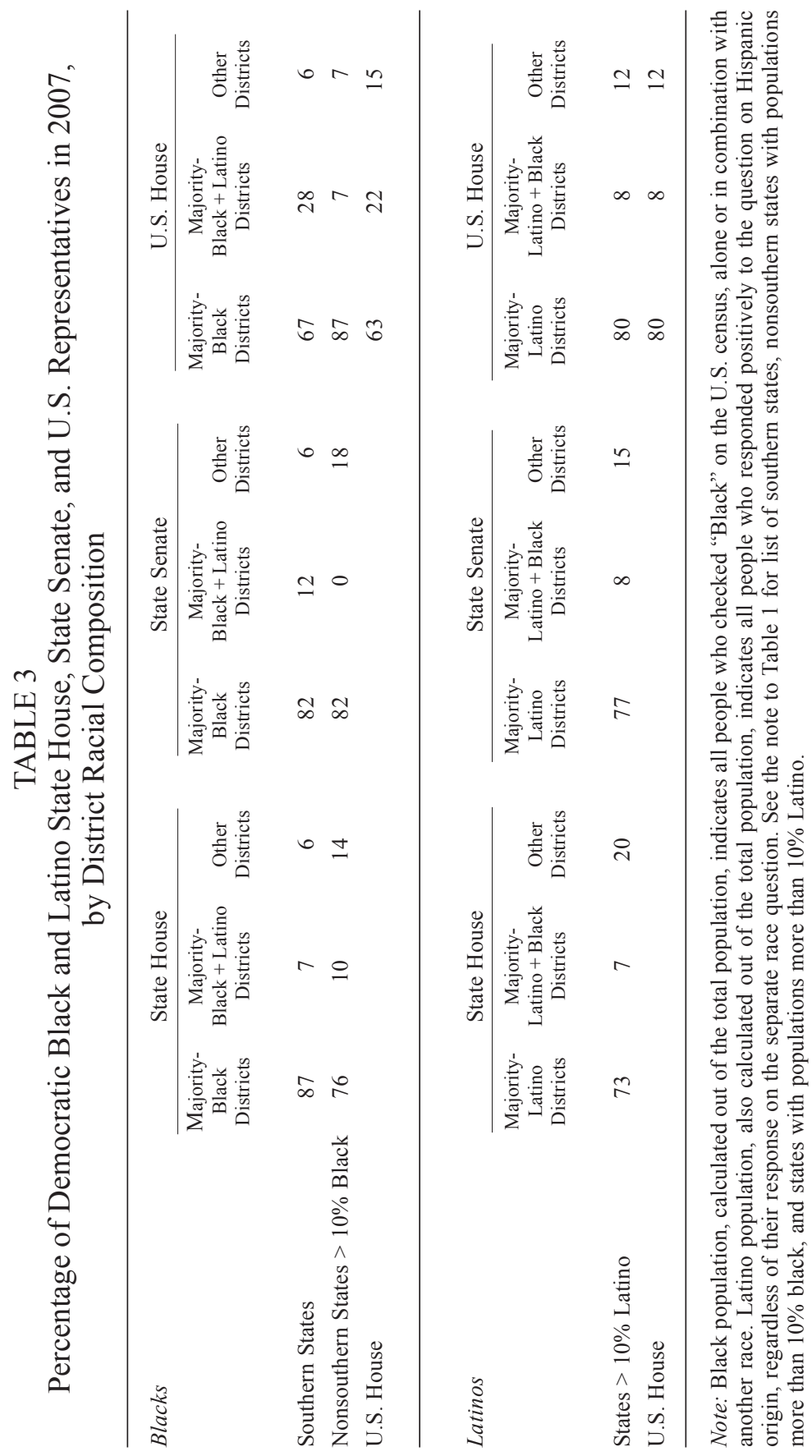


Table 4 confirms these conclusions from another perspective, breaking down districts into different categories by racial composition and showing the proportion of black legislators elected from each category. Table 4, Part A, reveals that the proportion of black legislators, unsurprisingly, rises as the proportion of the black population increases. Many black legislators win in $40 \%$ to $50 \%$ black districts, and even in $30 \%$ to $40 \%$ black districts for state senates and the U.S. House. Parts $\mathrm{B}$ and $\mathrm{C}$ make clear, however, that most of these legislators win in majority-minority districts, generally those in which blacks and Hispanics together form a majority. The share of black legislators is relatively low in districts where the non-Hispanic white population exceeds $55 \%$ or the combined black and Hispanic population falls below $45 \%$.

Latinos. Table 2 indicates the percentage of majority-Latino districts that elected Latino candidates to legislative office in 1992 and 2007. The share of majority-Latino state legislative districts represented by Latinos increased, albeit less than did the share of majority-black districts represented by African Americans. Latinos represented a slightly higher proportion of majority-Latino state house and senate legislative districts in 2007 than in 1992 - an increase from $75.0 \%$ to $76.9 \%$ in state senate districts and from $78.4 \%$ to $78.6 \%$ in state house districts. On the other hand, the share of majority-Latino U.S. House districts held by Latino representatives increased from $75.0 \%$ to $83.3 \%$. Unlike the number of majority-black districts, the number of majority-Hispanic districts grew substantially between 1992 and 2007. Table 2 shows that the number of majority-Latino state house and state senate districts leapt by roughly one-third. The number of majority-Latino congressional districts increased from 20 to 24, despite the loss of one majority-Latino district in New York following a Shawbased legal challenge. ${ }^{14}$

The increase in the number of Latino legislators elected from majority-Latino districts is mostly attributable to an increase in the number of majority-Latino districts. In contrast, most gains in the number of black officials stemmed from increases in the proportion of majority-black districts that these legislators won, rather than an increase in the number of such districts. The increased number of majority-Latino districts is unsurprising when we consider the growth in the Latino population (see Table 2). Of course, majority-Latino districts may lack a Latino majority in the electorate because of much higher noncitizenship rates and lower rates of voter turnout among Latinos compared to either whites or blacks. 


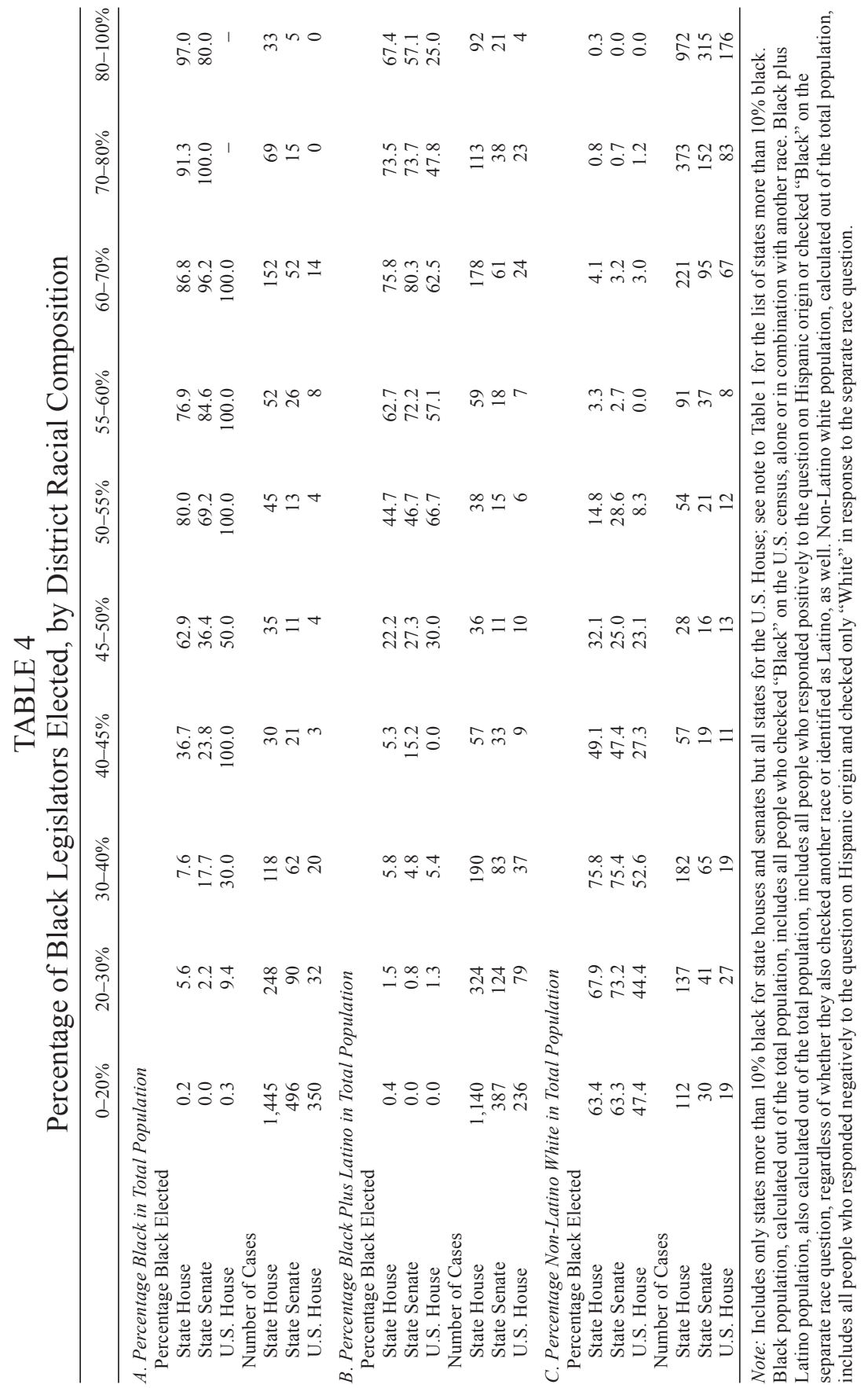


Table 2 also reports the percentage of majority-non-Latino districts represented by Latino legislators. Although the share of these districts won by Latino candidates increased slightly between 1992 and 2007, the percentage remained low. Only $4.9 \%$ of majority-nonLatino state house districts were represented by Latinos in 2007, up from $2.4 \%$ in 1992. Latinos represented 3.4\% of majority-non-Latino state senate districts in 2007, an increase of $0.9 \%$ over the $2.5 \%$ share held by Latinos in 1992. At the congressional level, there was a slight increase in the percentage of majority-non-Latino seats won by Latino candidates, from $0.5 \%$ to $1.2 \%$, resulting from a net gain of three congressional seats.

The percentage of Hispanic representatives elected to legislative office from majority-white districts is somewhat higher than the percentage of African American representatives elected from majoritywhite districts, especially if we consider African American state legislators from the South. Table 3 shows that $20 \%$ of Latino state representatives and $15 \%$ of Latino state senators won in districts where neither Latinos alone nor Latinos and African Americans in combination formed a majority. ${ }^{15}$ In the U.S. House, $12 \%$ of Latino members also represented majority-white districts. ${ }^{16}$ Nevertheless, over three-quarters of Latino legislators in the states considered here were still elected from districts with a Latino population majority.

Table 5 divides districts into categories by racial composition and presents the proportion of Latino legislators in each category. Part A demonstrates that the proportion of Latino legislators generally increases as the Latino population increases. Part $\mathrm{C}$ indicates that the proportion of Latinos elected in districts with a majority of non-Latino whites is relatively low. Part B suggests noncitizenship rates among Latinos, rather than white hostility, may be the major long-term barrier to higher rates of Latino representation. Latinos hold approximately $30 \%$ of the seats in $30 \%$ to $40 \%$ citizen Latino districts, with rates rising even higher for districts in the $40 \%$ to $50 \%$ citizen Latino range.

\section{Multivariate Analysis}

Our analysis shows clearly that most African American and Hispanic legislators win election in districts where members of their own ethnic or racial group form a majority, either alone or in combination with the other group. Yet this focus on majority-minority and majority-white districts does not allow us to assess if nonracial factors also play a major role in determining the race of a district's representative. This subsection addresses this possibility and compares the 


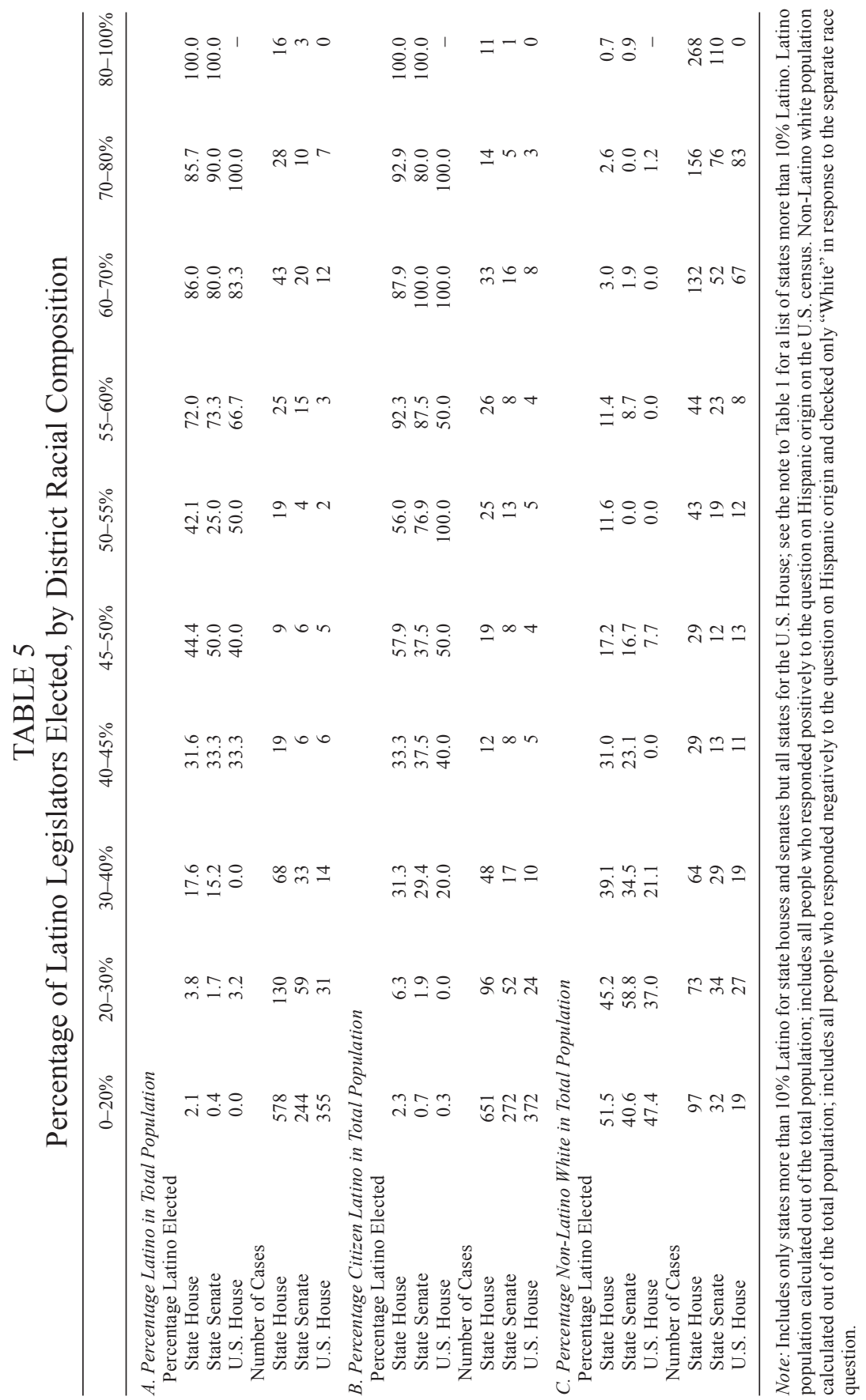


probability of a district having an African American or Hispanic legislator in 1992 and 2007.

Tables 6 and 7 replicate the multivariate logit analyses conducted by Lublin (1997) in The Paradox of Representation. Lublin's purpose was to determine if nonracial factors might also influence the election of minority officials. For example, districts with larger populations of elderly residents might be less prone to elect minority officials because of less tolerant attitudes among whites raised prior to the civil rights movement. On the other hand, districts with a high percentage of educated residents might elect minority officials at higher rates if the greater racial tolerance found among educated people in surveys translates into a greater willingness to elect minorities to public office. In addition to updating Lublin's analysis for the U.S. House, we updated results for state senates and state houses, but we included in our state legislative analyses only those states that had more than $10 \%$ of their populations constituted by the minority group being examined.

The results confirm Lublin's original findings that the racial composition of districts overwhelms other factors in determining the race of a district's representative. The coefficients on Proportion Black and Proportion Latino exert powerful influence on the election of black and Latino officials, respectively. The proportion of Latinos also appears to influence the election of black officials, once we remove the other nonracial variables.

We uncovered some differences from Lublin's original findings. For example, Proportion Urban in a district appears to influence the election of black state legislators in this more-recent analysis. Still, Proportion Urban's impact on the probability of a district electing a black official is far smaller than the power of the proportion of black constituents in the district. Greater success in urban districts may indicate higher rates of support for African American candidates among whites. Or, it might simply reflect the fact that coalitional districts in which black and Hispanic residents together form a majority are far more likely to exist in urban than in rural areas.

Unlike Lublin's previous research, this study did not find that the proportion of constituents residing in the state for at least five years-Lublin's rough proxy for the likelihood of those residents holding citizenship - influences whether or not a Latino candidate wins election. More-direct measures of citizenship show, however, that citizenship levels continue to play a role in determining whether or not a district elects a Latino legislator. The third data column for each legislative body type in Table 7 shows the coefficients and standard errors from a logistic regression of Latino Legislator on Proportion 


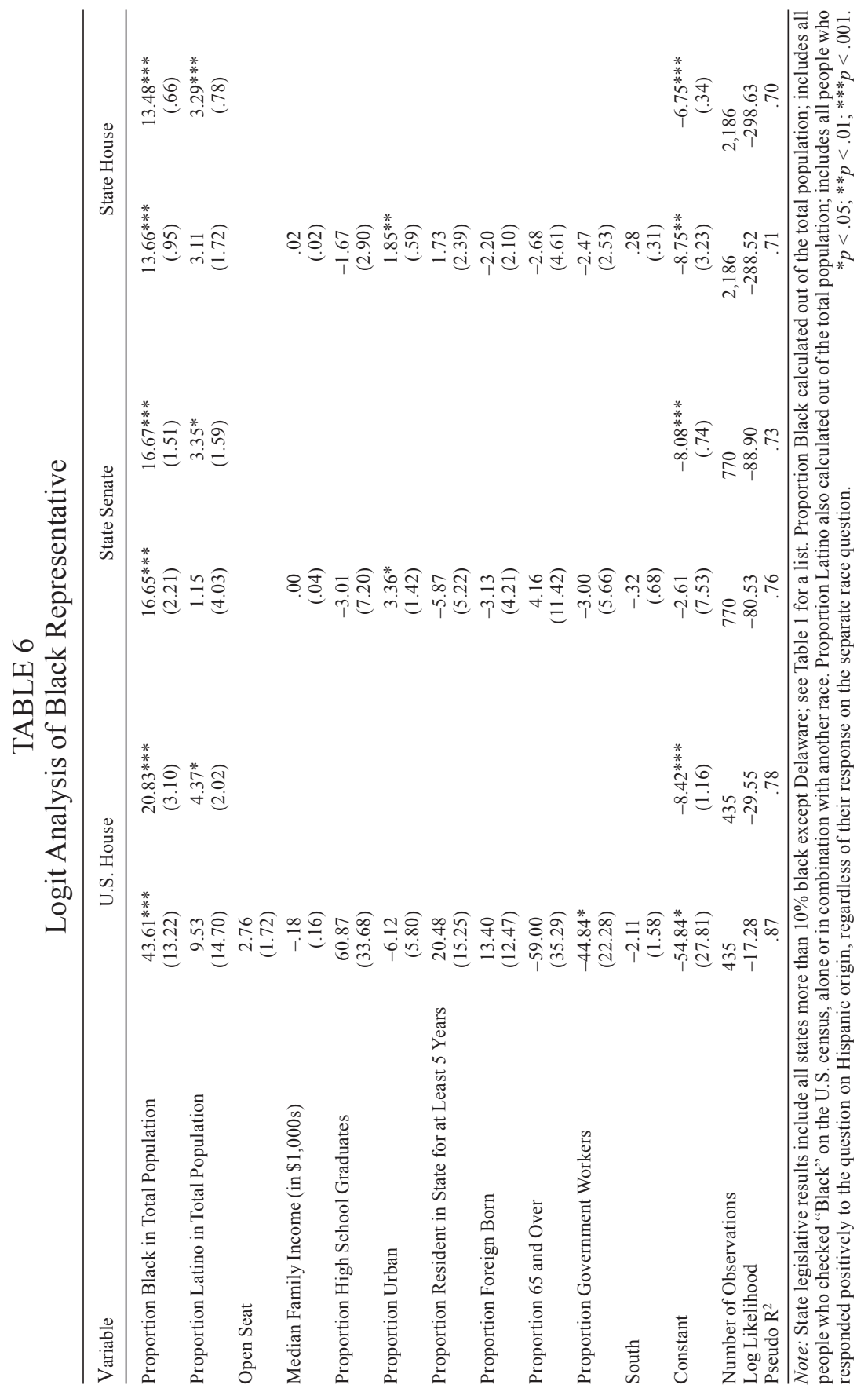




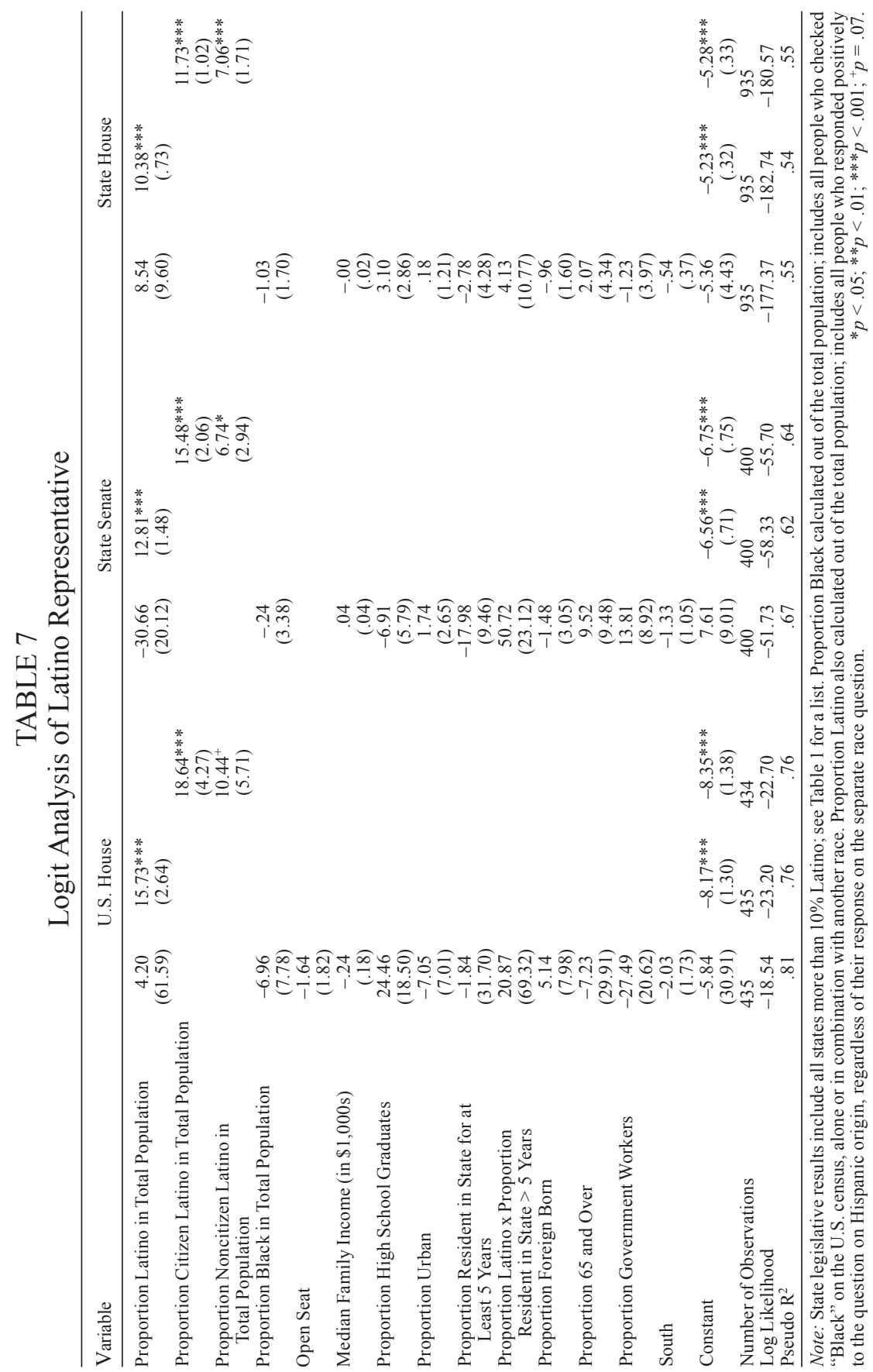


Citizen Latino and Proportion Noncitizen Latino in the total population. Not surprisingly, the presence of citizen Latinos in a district has a greater effect on the probability of that district electing a Latino legislator than does the presence of noncitizen Latinos. Nevertheless, adding more noncitizen Latinos to a district still increases the district's chance of electing a Latino legislator. If nothing else, the presence of noncitizens decreases the number of potential votes against a candidate supported by citizen Latinos in a district and thus increases the proportion of citizen Latinos in the electorate.

Probability of a Black Legislator. Table 8A shows the estimated probability of a district being represented by a black legislator. We calculated these estimates utilizing the logit models containing Proportion Black and Proportion Latino as independent variables with Proportion Latino set equal to 0 (that is, the second model displayed in Table 6 for each legislative body type). The Lublin 1990, U.S. House and Lublin 1992, U.S. House rows present estimates from the models used by Lublin in previous work, but we used the data only from 1990 and 1992 instead of the pooled time-series analysis across several decades that Lublin originally presented.

The probability of a district electing an African American to either the state senate or the state house in 2007 roughly mirrors the probability that a congressional district sent an African American legislator to Washington in 1990. African American candidates have approximately a one-in-five chance of winning in a $40 \%$ black state legislative district. According to the models, blacks have a $50 \%$ chance of winning in a $50 \%$ black state house district and a $56 \%$ probability of victory in a state senate district with the same racial composition. Put another way, two $50 \%$ black districts would probably elect one black state legislator. Districts that are $60 \%$ black have a $79 \%$ probability of electing a black state representative and an $87 \%$ probability of having a black state senator.

The model for the U.S. House seemingly indicates that African American candidates find it much easier to win election to that body than to the state legislature. The probabilities for the U.S. House should be viewed with caution, however, for they result from a model which relies on very limited data and is very sensitive to small changes in these data points. More specifically, the intentional creation and maintenance of new majority-black districts through racial redistricting has depleted the number of districts that fall into the $35 \%$ to $50 \%$ black range. (At the time of the 2006 election, 11 districts fell into this range, but black residents formed a majority in combination with Hispanic 

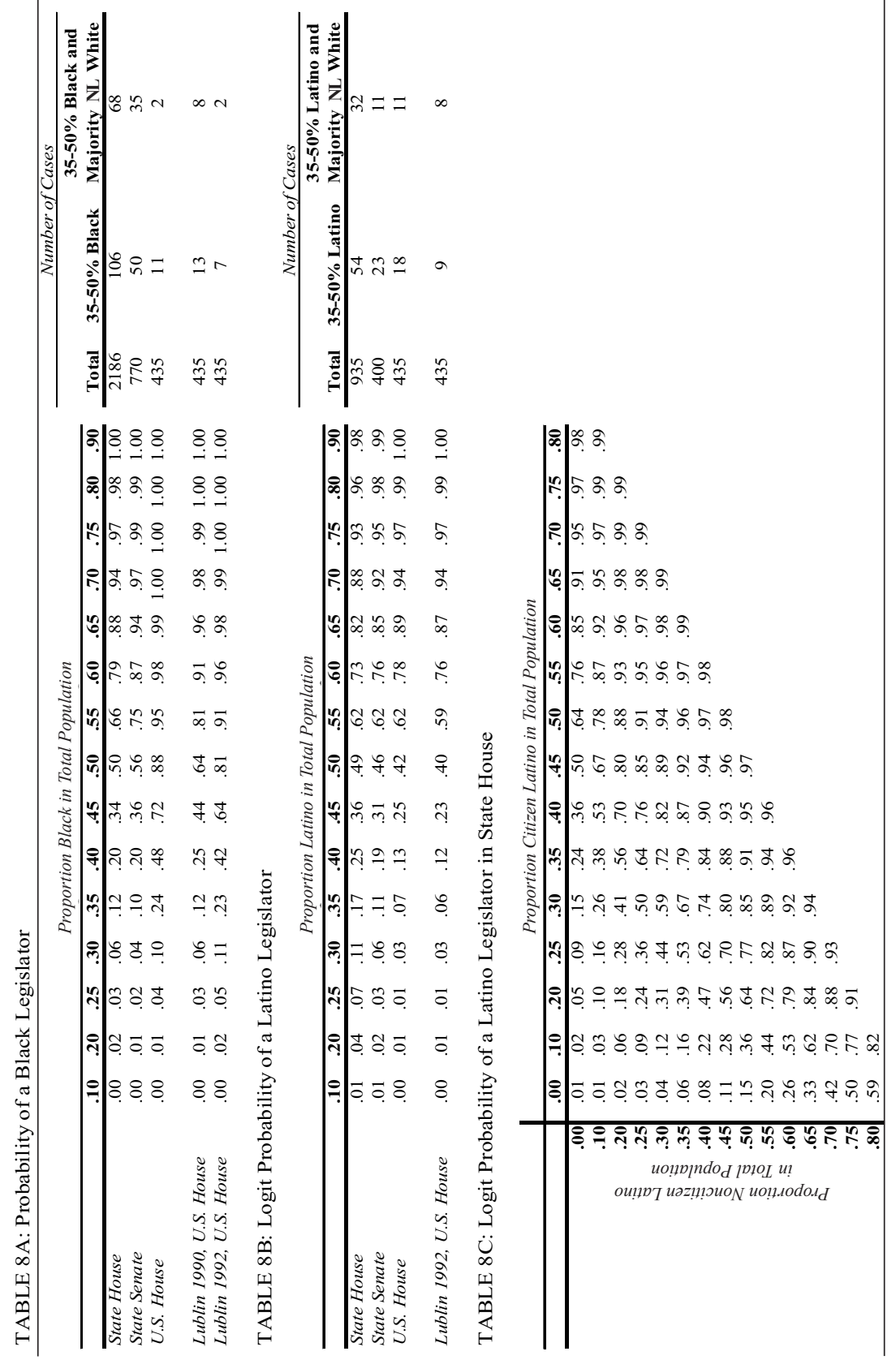
residents in 9 of these districts. $)^{17}$ Therefore, although models based on the 1990 and 1992 data suggest a dramatic increase in the probability of a district being represented by an African American in the U.S. House between these two years (see Table 8A), this estimated change flows largely from changes in the racial composition of congressional districts rather than from any change in voting behavior. The results from the state legislative models based on recent elections further support this conclusion: the number of state legislative districts in the critical range is much higher, and the estimated probability of an African American legislator representing a state district much more closely reflects the results derived from the U.S. House model for 1990 than 1992.

Probability of a Latino Legislator. Table $8 \mathrm{~B}$ presents the probability of a district electing a Latino legislator as derived from statistical models in which the only independent variable is Proportion Latino in Total Population (that is, the second model for each legislative body type presented in Table 7). All three models confirm that districts with populations that are more than $50 \%$ Latino continue to raise the estimated probability of a Latino legislator above $50 \%$. Fifty-five percent of Latino districts have a $62 \%$ chance of being represented by a Latino legislator in either the state legislature or the U.S. House. Approximately three-quarters of districts that are $60 \%$ Latino have Latino representatives, as do approximately $90 \%$ of districts that are $70 \%$ Latino.

The probabilities from Table $8 \mathrm{C}$ are derived from a model of state house elections containing separate independent variables for citizen Latinos and noncitizen Latinos in the total population (the probabilities are derived from the model shown in the last column of Table 7). ${ }^{18}$ As the first row (.00) of this table indicates, Latinos may start winning more victories in districts with white, non-Latino majorities once Latino citizenship rates increase. Districts in which citizen Latinos form $35 \%$ of the population (and there are no noncitizen Latinos) have an estimated $24 \%$ probability of electing a Latino state house member. Districts with populations that are $40 \%$ and $45 \%$ citizen Latino have a $36 \%$ and $50 \%$ chance, respectively, of being represented by a Latino legislator in the state House. Models for the election of Latino state senators and federal representatives produce similar results.

\section{Conclusion}

The central purposes of race-conscious redistricting since the passage of the original Voting Rights Act have been to prevent district 
boundaries from being used to minimize or cancel out minority voting strength (see, for example, McDonald 2003 and Parker 1990) and to provide minority voters with an opportunity to elect some of their preferred candidates. Race-conscious redistricting in its modern form thus grants to minorities some of the same opportunities available to whites by virtue of whites' majority status. As Chief Justice Warren explained in Allen v. State Board of Elections (1969), race-conscious redistricting in its modern form assured that minority participation in the political process was not merely a symbolic, yet ultimately ineffectual, act but instead one that allowed minorities to exercise the franchise in a meaningful way to elect minority-preferred candidates from some districts.

Although much time has passed, the evidence presented here demonstrates that the fundamental argument in favor of the creation of majority-minority districts remains valid today: the vast majority of minority legislators still win election from districts where minority groups form the majority of the population. The share of majoritynonblack districts with African American state legislators and congressional representatives remains extremely low-5\% or less in 2007 . This rarity is evident in both the South and the nonsouthern states included in our analyses - that is, those states in which the minority population is substantial. Moreover, many of these African American legislators won election not from majority-white districts, but from districts where African Americans and Hispanics together formed a population majority. And many of the remaining African American successes can be attributed to districts where African Americans and Latinos, while not forming a majority of the general electorate, still constitute a majority of the electorate in the Democratic primary.

Majority-Hispanic districts play a similarly crucial role in the election of Hispanic officials. The share of majority-non-Hispanic districts electing Latino candidates to legislative office is minusculein the 10 states studied here, less than $5 \%$ of such districts elected Latinos in 2007. Majority-Latino districts continue to elect the overwhelming majority of Latino officials.

In sum, since race-conscious redistricting and the creation of effective minority districts remain the basis upon which most African American and Latino officials gain election, the Voting Rights Actincluding Sections 2 and 5-remains a valuable tool to protect the ability of minorities to elect their preferred candidates. 
David Lublin <dlublin@american.edu> is Professor of Government, School of Public Affairs, American University, 4400 Massachusetts Ave., NW Washington, DC 20016-8130. Thomas L. Brunell<tbrunell@utdallas.edu> is Professor of Political Science, University of Texas, Dallas, $800 \mathrm{~W}$. Campbell Road, Richardson, TX 75080. Bernard Grofman <bgrofman@uci.edu> is Professor of Political Science, University of California, Irvine, 2291 Social Sciences Plaza B, Mail Code 5100, Irvine, CA 92697. Lisa Handley $<$ rhandley@aol.com> is President of Frontier International Electoral Consulting.

\section{NOTES}

1. There is also a debate about the effect of minority elected officials on public policy affecting minority interests. Brunell and Grofman (2008), Grofman and Brunell (2006), Lublin and Segura (2008), and Pildes (1995) have all reviewed the literature on race-conscious redistricting and its consequences. More specifically, some authors have argued that concentrating African American constituents, who vote overwhelmingly Democratic, in majority-black districts can aid the election of Republicans in adjoining districts and thus create a trade-off between the creation of districts likely to elect African American candidates and overall legislative support for policies favored by African Americans (Bullock 1995; Cameron, Epstein, and O'Halloran 1996; Epstein and O'Halloran 1999; Hill 1995; Lublin 1997, 1999; Lublin and Voss 2000; Swain 1995; Thernstrom 1987; Thernstrom and Thernstrom 1999). The majority opinion for the Supreme Court in Georgia v. Ashcroft essentially endorsed this view, allowing reductions in the proportion of black voters in some districts if these reductions are part of an effort to expand minority influence and the effort is supported by minority legislators. Other scholars have argued that the creation of majority-black districts has had little influence on electoral or policy outcomes, or even promoted the adoption of policies favored by African American constituents (Canon 1999; Grofman 2006; Grofman and Handley 1995, N.d.; McClain 1994; Petrocik and Desposato 1998; Shotts 2003). Legal scholars have questioned if Section 5, renewed and largely unchanged except for efforts by Congress to strengthen it by overturning Georgia v. Ashcroft and another Supreme Court decision (described later), remains necessary or will survive constitutional scrutiny by the U.S. Supreme Court (Gerken 2006; Issacharoff 2004; Pildes 2007b; U.S. Congress, Senate, 2006). Some analysts have suggested, however, that Congress took the only politically viable approach and that the Court should uphold the renewed Section 5 (Canon 2008; Persily 2007). These debates are interesting and important, but our article focuses exclusively on the necessity of race-conscious redistricting for the election of minority candidates.

2. In the majority-minority districts, the size of the minority electorate allows minorities to elect their candidates of choice even when voting is racially polarized in both the primary and general elections. In the southern districts, minorities can elect their candidates of choice in the primary election of a given party even when voting is racially polarized because minority voters outnumber white voters in that primary. Minority constituents can expect their preferred candidate to win in the general elec- 
tion if there is also a sufficiently high and reliable level of white crossover voting for the candidate of that party.

3. Section 2 applies nationwide. Section 5 applies only to certain "covered jurisdictions." These jurisdictions remain primarily in the southern states that historically showed the greatest resistance to black voter enfranchisement. Revisions to the formula triggering Section 5 coverage led to the extension of coverage (in whole or in part) to various southwestern jurisdictions, Alaska, and other jurisdictions, including three boroughs of New York City.

4. Candidates preferred by minority voters are often referred to as "minority candidates of choice." Here we use minority candidates as a proxy for candidates of choice, because courts have considered analyses of the election of minority candidates of choice as more probative (Persily 2007). Nevertheless, individual minority candidates may not be candidates of choice, just as individual white candidates may be preferred to minority candidates.

5. We identified African American legislators using the National Black Caucus of State Legislators directory and data provided by the Joint Center for Political and Economic Studies, in addition to personal knowledge and inquiries. A relatively small number of legislators were identified as black by some sources and as Latino by others, but we classified all but one as belonging to a single group. Adam Clayton Powell IV is the only legislator in the dataset classified as both Latino and African American.

6. The 11 southern states are Alabama, Arkansas, Florida, Georgia, Louisiana, Mississippi, North Carolina, South Carolina, Tennessee, Texas, and Virginia. The 8 nonsouthern states are Delaware, Illinois, Maryland, Michigan, Missouri, New Jersey, New York, and Ohio. Almost all 1992 data are from Handley, Grofman, and Arden 1998, although some U.S. House data are from the Almanac of American Politics (1994). Data were not available for Alabama or Maryland state house and senate elections or for Michigan state senate elections in 1992, because elections had not yet been held in these states under the post-1990 redistricting plan. We substitutes data from 1994 for these cases.

7. The proportion of blacks elected to Congress in some states changed even when the number of minority representatives did not, simply because the total number of representatives increased or decreased in some of these states because of reapportionment after the 2000 elections.

8. We use the terms Latino and Hispanic interchangeably in this article. The 10 states include Arizona, California, Colorado, Florida, Illinois, Nevada, New Jersey, New Mexico, New York, and Texas. All 1992 data are from Handley, Grofman, and Arden 1998. We identified Latino legislators using the National Association of Latino Elected and Appointed Officials directory, in addition to personal knowledge and inquiries. A relatively small number of legislators were identified as black by some sources and as Latino by others, but we classified all but one legislator as belonging to just one group. See note 5 .

9. Of course, this relationship may vary across the country, and courtscorrectly, in our view - prefer jurisdiction-specific analysis in litigation.

10. Equivalent tables containing the voting-age population data for 2007 can be found in an earlier version of this article (Lublin et al. 2009). The earlier version also contains the data for each state included in the southern and nonsouthern regions examined here. 
11. In these situations, we believe it is quite plausible to assume that the black victor was the candidate of choice for the black community. But, of course, the accuracy of this conflation is a matter for empirical investigation in any situation that arouses doubt.

12. Four of the six African American legislators who represented majoritynonblack districts in 2007 originally won election in majority-black districts: Sanford Bishop Jr. (GA 02), Eddie Bernice Johnson (TX 30), Sheila Jackson-Lee (TX 18), and Mel Watt (NC 12). Districts in Georgia, North Carolina, and Texas were redrawn in deference to the Shaw v. Reno line of cases. Non-Hispanic whites formed a majority of the 2000 population in none of the southern U.S. House districts represented by African Americans in 2007.

13. Furthermore, a closer look at the racial composition of the limited number of specific districts with non-Hispanic white majorities from which African American legislators were elected reveals that many (more than half in the case of the South) of these districts have substantial—although not majority - minority populations. See Grofman, Handley, and Lublin 2001 for a far more detailed discussion of these districts that are not majority-minority but still feature effective minorities.

14. Nydia Velazquez won the seat in 1992, when the district was a majorityLatino district, and the representative, a Latina, continued to hold the seat after it was redrawn without a Latino majority.

15. More than one-third of the districts with non-Hispanic white majorities that elect Latinos to office have substantial (more than 35\%) Hispanic populations. See Grofman, Handley, and Lublin 2001 for a discussion of non-majority-minority districts that are effective at electing minority-preferred candidates to office.

16. The proportion of Latino representatives elected from districts with a nonLatino electoral majority is likely slightly higher than these numbers suggest, because districts with a Latino population majority may lack a Latino electoral majority, as a result of lower citizenship and voter turnout rates among Latinos.

17. The number of districts between $35 \%$ and $50 \%$ black in which black residents did not form a majority with Hispanic residents fell from 8 in 1990 to 2 in 1992.

18. Models based on state senate and U.S. House elections data produce similar results. Models using Proportion Citizen Latino in Total Population produce probabilities very similar to those derived from models like the one shown here when the share of noncitizen Latinos is set at 0 .

\section{REFERENCES}

Allen v. State Board of Elections. 1969. 393 U.S. 544.

Barone, Michael, and Richard E. Cohen. 1994. Almanac of American Politics. Washington, DC: National Journal Group.

Beer v. United States. 1976. 425 U.S. 130.

Brunell, Thomas L., and Bernard Grofman. 2008. "Evaluating the Impact of Redistricting on District Homogeneity, Political Competition, and Political Extremism in the U.S. House of Representatives, 1962 to 2006." In Designing Democratic Government: Making Institutions Work, ed. Margaret Levi, James Johnson, Jack Knight, and Susan Stokes. New York: Russell Sage Foundation. 
Bullock, Charles S., III. 1995. "Affirmative Action Districts: In Whose Faces Will They Blow Up?" Campaigns and Elections (April): 22-23.

Cameron, Charles, David Epstein, and Sharyn O'Halloran. 1996. "Do Majority-Minority Districts Maximize Substantive Black Representation in Congress?" American Political Science Review 90: 794-812.

Canon, David T. 1999. Race, Redistricting, and Representation: The Unintended Consequences of Black Majority Districts. Chicago, IL: University of Chicago Press.

Canon, David T. 2008. "Renewing the Voting Rights Act: Retrogression, Influence, and the 'Georgia v. Ashcroft' Fix." Election Law Journal 7: 3-24.

Davidson, Chandler, and Bernard Grofman, eds. 1994. Quiet Revolution in the South: The Impact of the Voting Rights Act, 1965-1990. Princeton, NJ: Princeton University Press.

Epstein, David, and Sharyn O'Halloran. 1999. "A Social Science Approach to Race, Redistricting, and Representation.” American Political Science Review 93: 187-91.

Gerken, Heather. 2006. "A Third Way for the Voting Rights Act: Section 5 and the OptIn Approach.” Columbia Law Review 106: 708-52.

Grofman, Bernard. 2006. "Operationalizing the Section 5 Retrogression Standard of the Voting Rights Act in the Light of Georgia v. Ashcroft: Social Science Perspectives on Minority Influence, Opportunity and Control." Election Law Journal 5: 250-82.

Grofman, Bernard, and Thomas Brunell. 2006. "Extending Section 5: Law and Politics." In The Future of the Voting Rights Act, ed. David L. Epstein, Rodolfo O. de la Garza, Sharyn O’Halloran, and Richard H. Pildes. New York: Russell Sage Foundation.

Grofman, Bernard, and Lisa Handley. N.d. “An Examination of the 2001 Georgia State Senate Plan in the Light of the Georgia v. Ashcroft Non-Retrogression Standard: Social Science Perspectives." School of Social Sciences, University of California.

Grofman, Bernard, and Lisa Handley. 1989. "Minority Population and Black and Hispanic Congressional Success in the 1970s and 1980s." American Politics Quarterly 17: 436-45.

Grofman, Bernard, and Lisa Handley. 1991. "The Impact of the Voting Rights Act on Black Representation in Southern State Legislatures." Legislative Studies Quarterly 16: 111-28.

Grofman, Bernard, and Lisa Handley. 1995. "1990s Issues in Voting Rights.” University of Mississippi Law Journal 65: 205-70.

Grofman, Bernard, Lisa Handley, and David Lublin. 2001. "Drawing Effective Minority Districts: A Conceptual Framework and Some Empirical Evidence." North Carolina Law Review 79: 1383-1430.

Grofman, Bernard, Lisa Handley, and Richard G. Niemi. 1992. Minority Representation and the Quest for Voting Equality. New York: Cambridge University Press.

Handley, Lisa, Bernard Grofman, and Wayne Arden. 1998. "Electing Minority-Preferred Candidates to Legislative Office: The Relationship between Minority Percentages in Districts and the Election of Minority-Preferred Candidates." In Race and Redistricting in the 1990s, ed. Bernard Grofman. New York: Algora.

Hill, Kevin A. 1995. "Does the Creation of Majority Black Districts Aid Republicans? An Analysis of the 1992 Congressional Elections in Eight Southern States." Journal of Politics 59: 384-401. 
Issacharoff, Samuel. 2004. "Is Section 5 of the Voting Rights Act a Victim of Its Own Success?" Columbia Law Review 104: 1710-31.

Lublin, David. 1997. The Paradox of Representation: Racial Gerrymandering and Minority Interests in Congress. Princeton, NJ: Princeton University Press.

Lublin, David. 1999. "Racial Redistricting and African American Representation: A Critique of 'Do Majority-Minority Districts Maximize Black Substantive Representation in Congress." American Political Science Review 93: 183-86.

Lublin, David, and Gary Segura. 2008. "An Evaluation of the Electoral and Behavioral Impacts of Majority-Minority Districts." In Designing Democratic Government: Making Institutions Work, ed. Margaret Levi, James Johnson, Jack Knight, and Susan Stokes. New York: Russell Sage Foundation.

Lublin, David, and D. Stephen Voss. 2000. "Racial Redistricting and Realignment in Southern State Legislatures.” American Journal of Political Science 44: 792-810.

Lublin, David, Thomas L. Brunell, Bernard Grofman, and Lisa Handley. 2009. "Has the Voting Rights Act Outlived Its Usefulness? In a Word, 'No'.” 19 January 2009. http://papers.ssrn.com/sol3/papers.cfm?abstract_id=1329442 (August 1, 2009).

McClain, Paula D. 1994. "Book Review: Black Faces, Black Interests." Journal of Politics 56: 1145-48.

McDonald, Laughlin. 2003. The Voting Rights Odyssey: Black Enfranchisement in Georgia. UK: Cambridge University Press.

Northwest Austin Municipal Utility District Number One v. Mukasey. 2008. 557 F.Supp.2d, D.C.

Parker, Frank. 1990. Black Votes Count: Political Empowerment in Mississippi after 1965. Chapel Hill: University of North Carolina Press.

Persily, Nate. 2007. "The Promise and Pitfalls of the New Voting Rights Act." Yale Law Journal 117: 174-253.

Petrocik, John R., and Scott W. Desposato. 1998. "The Partisan Consequences of Majority-Minority Redistricting in the South, 1992 and 1994." Journal of Politics 60: $613-33$.

Pildes, Richard H. 1995. "The Politics of Race (Review of Davidson and Grofman, eds.: Quiet Revolution in the South)." Harvard Law Review 108: 1359-92.

Pildes, Richard H. 2007a. "The Future of Voting Rights Policy: From Anti-discrimination to the Right to Vote." Howard University Law Journal 49: 741-66.

Pildes, Richard H. 2007b. "Political Avoidance, Constitutional Theory, and the VRA." Yale Law Journal 117: 148-54.

Pildes, Richard H., and Richard G. Niemi. 1993. "Expressive Harms, 'Bizarre Districts,' and Voting Rights: Evaluating Election-District Appearances after Shaw v. Reno." Michigan Law Review 92: 483-587.

Shaw v. Reno. 1993. 509 U.S. 630.

Shotts, Kenneth W. 2003. "Does Racial Redistricting Cause Conservative Policy Outcomes? Policy Preferences of Southern Representatives in the 1980s and 1990s." Journal of Politics 65: 216-26.

Swain, Carol M. 1995. Black Faces, Black Interests: The Representation of African Americans in Congress. Enlarged edition. Cambridge, MA: Harvard University Press. 
Thernstrom, Abigail. 1987. Whose Votes Count? Affirmative Action and Minority Voting Rights. Cambridge, MA: Harvard University Press.

Thernstrom, Stephen, and Abigail Thernstrom. 1999. America in Black and White: One Nation, Indivisible. New York: Simon and Schuster.

U.S. Congress. Senate. Committee on the Judiciary. 2006. "An Introduction to the Expiring Provisions of the Voting Rights Act and Legal Issues Relating to Reauthorization." 109th Cong., 2d sess., 9 May.

U.S. Congress. Senate. Committee on the Judiciary. 2006. "An Introduction to the Expiring Provisions of the Voting Rights Act and Legal Issues Relating to Reauthorization." 109th Cong., 2d sess., 9 May.

U.S. Congress. Senate. Committee on the Judiciary. 2006. "Understanding the Benefits and Costs of Section 5 Pre-Clearance." 109th Cong., 2d sess., 17 May.

Voting Rights Act. 1965, 1982, 2006. 42 USC 1973. 
